\title{
Characteristics of the Romanian CIF Imports during the Period 01.01.2016 - 31.10.2016
}

\author{
Wiegand Helmut Fleischer ${ }^{1, *}$ \\ ${ }^{1}$ Lucian Blaga University of Sibiu, Faculty of Engineering, Department for Industrial Engineering and \\ Management, 550024 Sibiu, Romania
}

\begin{abstract}
The aim of this paper is to analyze the Romanian CIF imports during the period 01.01.2016-31.10.2016. My research goal is to identify the most important section of CIF imports during the analyzed period and the main structural modifications in evolution of the Romanian imports. The expected results are to know the most important import section of the Combined Nomenclature, the structural modification in evolution of these industries and the most important partner countries.
\end{abstract}

\section{Introduction}

For a better understanding of the Romanian economy, it is important to analyze the Romanian commercial relations. The characteristics of the Romanian CIF imports will give us important results regarding the main industries and the most important partner countries.

Under the Incoterms 2010 standard published by the International Chamber of Commerce, CIF means "the seller pays for the carriage of the goods up to the named port of destination. Risk transfers to buyer when the goods have been loaded on board the ship in the country of Export." [13].

The CIF price (i.e. cost, insurance and freight price) is "the price of a good delivered at the frontier of the importing country, including any insurance and freight charges incurred to that point, or the price of a service delivered to a resident, before the payment of any import duties or other taxes on imports or trade and transport margins within the country" [14].

\section{Sections}

In the period 01.01. - 31.10.2016 CIF imports amounted to 55671.7 million euro and increased with $6.4 \%$ as against the period 01.01. - 31.10.2015 [10].

In the structure of exports, six sections of the Combined Nomenclature hold $71.8 \%$ of total imports, as follows (table 1).

The main structural modifications came up in the evolution of imports by $\mathrm{CN}$ sections in the period 01.01.-31.10.2016 as against the period 01.01. - 31.10.2015, consists of: - XVII - increasing with 17.4 percentage points;

\footnotetext{
* Corresponding author: wiegand.fleischer@ulbsibiu.ro
} 
- VI - increasing with 7.1 percentage points;

- VII - increasing with 6.8 percentage points;

- XVI - increasing with 6.0 percentage points;

- V - decreasing with 13.6 percentage points;

- XV - decreasing with 1.0 percentage points [10].

Table 1. CIF Imports during the period 01.01. - 31.10.2016 [10]

\begin{tabular}{|c|c|c|c|}
\hline Section of the Combined Nomenclature (CN) & $\begin{array}{c}\text { Value } \\
\text { - million } \\
\text { euro - }\end{array}$ & $\begin{array}{c}\text { Structure in } \\
\text { \% as against } \\
\text { total imports }\end{array}$ & $\begin{array}{c}\text { In \% as } \\
\text { against 01.01. - } \\
\mathbf{3 1 . 1 0 . 2 0 1 5}\end{array}$ \\
\hline $\begin{array}{c}\text { XVI Machinery and mechanical appliances; } \\
\text { electrical equipment; sound and image recorders } \\
\text { and reproducers }\end{array}$ & 15558.2 & 27.9 & 106.0 \\
\hline XV Base metals and articles of base metals & 5682.5 & 10.2 & 99.0 \\
\hline XVII Vehicles and associated transport equipment & 5680.1 & 10.2 & 117.4 \\
\hline VI Chemicals products & 5647.1 & 10.1 & 107.1 \\
\hline VII Plastics, rubber and articles thereof & 4162.0 & 7.5 & 106.8 \\
\hline V Mineral products & 3273.5 & 5.9 & 86.4 \\
\hline
\end{tabular}

Imports of section XVI holding $27.9 \%$ of total imports in the period 01.01. 31.10 .2016 , holding the first place and registered an increase of $6.0 \%$ as against the same period in 2015 .

In this section, the chapters are:

- Chapter "Machinery and mechanical appliances; electrical equipment; sound and image recorders and reproducers" holds 8627.7 million euro imports CIF, representing $55.5 \%$ in total section, $15.5 \%$ in total imports CIF and registered an increase of $10.0 \%$ in comparison with the period 01.01. - 31.10.2015;

- Chapter "Boilers, turbines engines, mechanical apparatus and devices, parts thereof" holds 6930.5 million euro imports CIF, representing $44.5 \%$ in total section, $12.4 \%$ of total exports FOB in the period 01.01. - 31.10.2016 and registered an increase of $1.4 \%$ in comparison with the period 01.01. -31.10 .2015 [10].

The second place is held by the imports of section XV with an amount 5682.5 million euro and representing $10.2 \%$ in total imports CIF and registered a decrease of $1.0 \%$ in comparison with the period $01.01-31.10 .2015$.

In this section, the chapter are:

- Chapter "Products of pig-iron, iron and steel" holds 1704.1 million euro of the imports CIF and registered an increase of $1.7 \%$ in comparison with the period 01.01. - 31.10.2015; - Chapter "Pig-iron, iron and steel" holds 1699.4 million euro imports CIF and registered an important decrease of $8.7 \%$ in comparison with the period 01.01. - 31.10.2015;

- Chapter "Aluminium and articles thereof" holds 705.2 million euro imports CIF and registered a decrease of $2.4 \%$ in comparison with the period 01.01. - 31.10.2015;

- Chapter "Miscellaneous articles of base metal" holds 559.4 million euro imports CIF and registered an increase of $10.8 \%$ in comparison with the period 01.01. - 31.10.2015;

- Chapter "Copper and articles thereof" holds only 530.3 million euro imports CIF, but registered also a decrease of $0.4 \%$ in comparison with the period 01.01. - 31.10.2015;

- Chapter "Tools and implements, cutlery of base metal" holds 265.6 million euro imports CIF and registered an increase of $13.5 \%$ in comparison with the period 01.01 - 31.10.2015; - Chapter "Zinc ads articles thereof" holds 64.2 million euro imports CIF and registered an important increase of $4.4 \%$ in comparison with the period 01.01. -31.10 .2015 ;

- Chapter "Other base metals; cermets" holds 60.3 million euro imports CIF and registered an important increase of $11.9 \%$ in comparison with the period 01.01. - 31.10.2015;

- Chapter "Nickel and articles thereof" holds 37.9 million euro imports CIF and registered an important increase of $0.7 \%$ in comparison with the period 01.01. -31.10 .2015 ; 
- Chapter "Lead and articles thereof" holds 36.3 million euro imports CIF and registered an important increase of 59.0\% in comparison with the period 01.01. - 31.10.2015;

- Chapter "Tin and articles thereof" holds 19.8 million euro imports CIF and registered an important increase of $60.3 \%$ in comparison with the period 01.01. - 31.10.2015 [10].

Imports of section XVII hold the third place as weight in total imports CIF with 5680.1 million euro, registering an increase of $17.4 \%$ as against the period 01.01. - 31.10.2015.

In this section, the chapter are:

- Chapter "Vehicles, tractors and other ground vehicles" holds 5346.8 million euro of the imports CIF and represent $94.1 \%$ of total section and $9.6 \%$ of total imports CIF in the period 01.01. - 31.10.2016;

- Chapter "Railway or tramway locomotives and rolling-stock" holds 131.5 million euro imports CIF and registered an important increase of $135.7 \%$ in comparison with the period 01.01. - 31.10.2015;

- Chapter "Aircrafts, spacecrafts" holds 178.2 million euro imports CIF and registered an important increase of $69.8 \%$ in comparison with the period 01.01. - 31.10.2015;

- Chapter "Ships, boats and float structures" holds only 23.7 million euro imports CIF, but registered also an important increase of $104.1 \%$ in comparison with the period 01.01 . 31.10.2015 [10].

Imports of section VI, hold the fourth place as weight in total imports CIF with 5647.1 million euro, registering an increase with $7.1 \%$ as against the period 01.01. - 31.10.2015.

In this section, the chapter are:

- Chapter "Pharmaceutical products" holds 2280.9 million euro of the imports CIF and registered an increase of $8.9 \%$ in comparison with the period 01.01.-31.10.2015;

- Chapter "Miscellaneous chemical products" holds 811.7 million euro imports CIF and registered an increase of $11.5 \%$ in comparison with the period 01.01. - 31.10.2015;

- Chapter "Essentials oils and resinoids; perfumery, cosmetic or toilet preparations" holds 503.4 million euro imports CIF and registered an increase of $15.4 \%$ in comparison with the period 01.01. - 31.10.2015;

- Chapter "Organic chemicals" holds 479.7 million euro imports CIF and registered an important increase of $18.6 \%$ in comparison with the period 01.01. - 31.10.2015;

- Chapter "Fertilizers" holds 422.2 million euro imports CIF and registered an increase of $21.7 \%$ in comparison with the period 01.01. - 31.10.2015;

- Chapter "Tanning or dyeing extracts; tannins and their derivates; dyes, pigments and other dyestuff; paints and varnishes; putty and mastics; inks" holds only 367.6 million euro exports CIF, but registered also an increase of $5.5 \%$ in comparison with the period 01.01. 31.10.2015;

- Chapter "Soap; washing and lubricating preparations, dental wax, modeling pastes" holds 350.0 million euro imports CIF and registered an increase of $11.6 \%$ in comparison with the period 01.01. - 31.10.2015;

- Chapter "Inorganic chemicals" holds 222.4 million euro imports CIF and registered an increase of $7.6 \%$ in comparison with the period 01.01. - 31.10.2015;

- Chapter "Albuminoidal substances; modified starch; glues; enzymes" holds 121.4 million euro imports CIF and registered an increase of $1.4 \%$ in comparison with the period 01.01. 31.10.2015;

- Chapter "Explosives; pyrotechnic products; matches; pyrophoric alloys; certain combustible preparation" holds 56.5 million euro imports CIF and registered an increase of $6.4 \%$ in comparison with the period 01.01. - 31.10.2015;

- Chapter "Special woven fabrics; tufted textile fabrics; lace, tapestries; trimmings, embroidery" holds 29.7 million euro imports CIF and registered a decrease of $7.7 \%$ in comparison with the period 01.01. -31.10 .2015 [10]. 
Imports of section VII, hold the fifth place as weight in total imports CIF with 4162.0 million euro and registered an increase with $6.8 \%$ as against the period 01.01. - 31.10.2015.

In this section, the chapter are:

- Chapter "Plastics and articles thereof" holds 3124.9 million euro of the imports CIF and registered an important increase of 7.3\% in comparison with the period 01.01.-31.10.2015;

- Chapter "Rubber and articles thereof" holds 1037.1 million euro imports CIF and registered an increase of 5.1\% in comparison with the period 01.01. - 31.10.2015 [10].

Imports of section $\mathrm{V}$ Mineral products - hold the sixth place as weight in total imports CIF with 3273.5 million euro, registering a decrease of $13.6 \%$ as against the period 01.01. 31.10.2015.

In this section, the chapter are:

- Chapter "Mineral fuels and oils; bituminous substances; mineral waxes" holds 2994.9 million euro of the imports CIF and registered a decrease of $14.6 \%$ in comparison with the period 01.01.-31.10.2015;

- Chapter "Ores, slag and ash" holds 169.1 million euro imports CIF and registered a decrease of $4.7 \%$ in comparison with the period 01.01. - 31.10.2015;

- Chapter "Salt; sulphur; stone; plaster; lime and cement" holds 109.5 million euro imports CIF and registered an increase of $2.7 \%$ in comparison with the period 01.01. -31.10 .2015$ [10].

Table 2. Structure of CIF imports by main groups of goods per month (value in million euro) [1-10]

\begin{tabular}{|c|c|c|c|c|c|c|}
\hline & \multicolumn{5}{|c|}{ Section of the Combined Nomenclature } & \\
\cline { 2 - 7 } Period & $\begin{array}{c}\text { XVI } \\
\text { Machinery and } \\
\text { mechanical } \\
\text { appliances; } \\
\text { electrical } \\
\text { equipment; } \\
\text { sound and } \\
\text { image } \\
\text { recorders and } \\
\text { reproducers }\end{array}$ & $\begin{array}{c}\text { XV } \\
\text { Base } \\
\text { metals } \\
\text { and } \\
\text { articles } \\
\text { of base } \\
\text { metals }\end{array}$ & $\begin{array}{c}\text { XVII } \\
\text { Vehicles } \\
\text { and } \\
\text { associated } \\
\text { transport } \\
\text { equipment }\end{array}$ & $\begin{array}{c}\text { VI } \\
\text { Chemical } \\
\text { products }\end{array}$ & $\begin{array}{c}\text { VII } \\
\text { Plastic, } \\
\text { rubber and } \\
\text { articles } \\
\text { thereof }\end{array}$ & $\begin{array}{c}\text { V } \\
\text { Mineral } \\
\text { products }\end{array}$ \\
\hline 01.2016 & 1303.9 & 450.0 & 450.0 & 488.0 & 334.4 & \\
\hline 02.2016 & 1487.0 & 536.6 & 536.6 & 626.9 & 421.4 & 250.1 \\
\hline 03.2016 & 1593.4 & 620.2 & 620.2 & 649.9 & 449.0 & 320.2 \\
\hline 04.2016 & 1515.8 & 570.9 & 570.9 & 559.2 & 429.2 & 292.5 \\
\hline 05.2016 & 1583.5 & 566.9 & 566.9 & 545.7 & 415.3 & 368.2 \\
\hline 06.2016 & 1601.2 & 587.0 & 587.0 & 526.8 & 418.8 & 341.3 \\
\hline 07.2016 & 1488.1 & 579.6 & 579.6 & 554.1 & 414.1 & 326.4 \\
\hline 08.2016 & 1482.5 & 512.0 & 512.0 & 570.5 & 400.8 & 447.9 \\
\hline 09.2016 & 1719.4 & 660.7 & 660.7 & 557.2 & 441.3 & 324.6 \\
\hline 10.2016 & 1783.4 & 596.3 & 596.3 & 568.0 & 437.9 & 377.3 \\
\hline$\sum$ & 15558.2 & 5680.1 & 5680.1 & 5647.1 & 4162.0 & 3273.5 \\
\hline
\end{tabular}

In the period 01.01.-31.10.2016, as against the same period in 2015, imports from the other 27 European Union (EU28) countries increased with $6.4 \%$, registering a weight of $77.3 \%$ in total imports of Romania [10].

The European Union countries are the most important import partners of Romania and is very import to focus on this commercial relations but also on the Romanian production in order to reduce the imports and to improve the trade balance of Romania.

Partner countries holding the first 10 places in total amount of imports in the period 01.01. -31.10 .2016 (representing $68.4 \%$ of total imports $=$ o. t. i.) were the following:

1. Germany $(20.7 \%$ o. t. i.),

2. Italy ( $10.3 \%$ o. t. i.), 
3. Hungary $(7.3 \%$ o. t. i.),

4. France $(5.6 \%$ o. t. i.),

5. Poland (5.1\% o. t. i.),

6. China (5.1\% o. t. i.),

7. Netherlands $(4.1 \%$ o. t. i. $)$,

8. Turkey $(3.8 \%$ o. t. i.),

9. Austria (3.6\% o. t. i.),

10. Russian Federation (2.8\% o. t. i.) [10].

In the period 01.01. - 31.10.2016, CIF imports amounted to 55671.7 million euro, with $6.4 \%$ more compared with the same period in 2015 .

\section{Conclusions}

The most important import section of the Combined Nomenclature in the period 01.01.31.10.2016 of the Romanian CIF imports are:

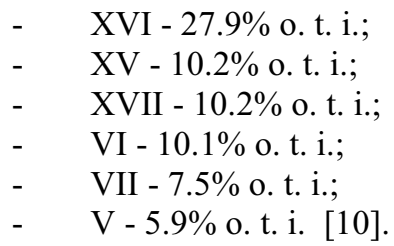

By implementing renewable energy projects, the cost of energy imports can be substantially reduced and this would have a beneficial effect on the trade balance of Romania [12].

Also, by implementing the most advanced technologies, we can save energy and increase productivity. For this reason, it is very important to import advanced technologies from countries with best performance in the technologic sector and not import outdated technologies.

We recommend the reviving of the agriculture and animal husbandry in Romania, so that the domestic production should meet, to a great extent, the need of the Romanian market and the surplus should be exported under favorable conditions [12].

In order to stabilize the trade balance of Romania, we recommend the decrease in imports as a result of the quantitative and qualitative improvement of the domestic production and a more efficient awareness of the consumers in Romania regarding the importance of supporting the Romanian industry and the Romanian entrepreneurs by purchasing Romanian products [11].

Romania 's economy has the potential to grow from year to year and to produce most of the products needed by its own population. To realize this important objectives, it is impetuous necessary to improve the efficiency of the production activity and the quality of the Romanian products and services. Thus we have the possibility to reduce the imports, to reach a balanced and even positive trade balance.

\section{References}

1. Institutul National de Statistica, Buletin Statistic de Comert Internaţional, 1/2016, 54-61 (2016)

2. Institutul National de Statistica, Buletin Statistic de Comert International, 2/2016, 54-61 (2016)

3. Institutul National de Statistica, Buletin Statistic de Comert Internațional, 3/2016, 54-61 (2016)

4. Institutul National de Statistica, Buletin Statistic de Comert International, 4/2016, 54-61 (2016)

5. Institutul National de Statistica, Buletin Statistic de Comert International, 5/2016, 54-61 (2016)

6. Institutul National de Statistica, Buletin Statistic de Comert International, 6/2016, 54-61 (2016)

7. Institutul National de Statistica, Buletin Statistic de Comert International, 7/2016, 54-61 (2016) 
8. Institutul National de Statistica, Buletin Statistic de Comert Internațional, 8/2016, 54-61 (2016)

9. Institutul National de Statistica, Buletin Statistic de Comert International, 9/2016, 54-61 (2016)

10. Institutul National de Statistica, Buletin Statistic de Comert International, 10/2016, 54-61 (2016)

11. W.H. Fleischer, Procedia Economics and Finance, 16, 256 (2014)

12. W.H. Fleischer, Relatiile economice romano-germane si Uniunea Europeana - Intre controverse si realizari, 283-284 (Editura Alma Mater, Sibiu, 2011)

13. $* * *$, http://en.wikipedia.org/wiki/Incoterms (2017)

14. ***, https://stats.oecd.org/glossary/detail.asp?ID=332 (2017) 